\title{
Budget Implementation in Higher Education
}

\author{
Asep Kurniawan, Tjutju Yuniarsih, Sumarto \\ Faculty of Economic and Business Education \\ Universitas Pendidikan Indonesia \\ asep.kurniawan12@student.upi.edu
}

\begin{abstract}
This study analyzed the implementation of the budget in universities. Implementation of the budget in question is how the budget preparation and how the implementation of the budget in universities. The method used in this research is a case study method with qualitative approach. The object of research conducted at the Institut Teknologi Bandung, Institut Pertanian Bogor, and Universitas Pendidikan Indonesia. In the budget there are many components that need to be formulated based on the type and priority needs. In the implementation of the budget is basically to note that the budgeting process in universities must deliver transparent and accountable manner. In the budget process there are components that need to be formulated based on priority component needs. Therefore, the need for such an ideal component : component in the learning process, managerial processes and research. In the process of budget execution has been carried out in a transparent manner with appropriate procedures and involving stakeholders such as financial directorate, directorate of planning, internal audit unit, the external auditors, as well as the corresponding work unit.
\end{abstract}

Keywords-Budget implementation, budgeting, higher education.

\section{INTRODUCTION}

Education has a strategic role, cannot negotiable. One element of education in the 1945 amendment that the financing of education. In mandemen the education budget is $20 \%$ of the state budget, this is a reliable instrument to create quality human and intact. National education finance will be effective if it is supported by a national financial management system powerful and synergistic. The purpose of education is the creation of a finance management effectiveness and efficiency, both related to the sources of financing and the way in its allocation. Finance management through effective, efficient, and transparent will show how it is obtained and the source of financing allocated appropriately so as to encourage high productivity.

Nevertheless the fact that occurs in Indonesia, the availability of sources of financing of education is still an obstacle. Minister of Education and Culture has set Standards for Higher Education Management through Permendikbud No. 49 of 2014 on National Education Standards High. In the Permendikbud set national standards, national standards of research, and national standards community service. The allocation of funds for education in Indonesia is low when compared with other countries in Southeast Asia. The education budget has been allocated $20 \%$ of the state budget, but most are still allocated for recurrent expenditure and employees. Whereas in Article 31, paragraph 4 of the 1945 Constitution clearly stated that the government has a constitutional obligation to prioritize the education budget by $20 \%$ of the national and regional budgets to meet the needs of education. In Article 46 of Law No. 20 of 2003 states that funding of education is a shared responsibility between the central government, local government, and society. Education budget is adequate and well managed by a State will have an impact on the process of implementation of quality education so as to produce quality human. Achievement of Human Development Index (HDI) of the UNDP (United Nations Development Program) indicates that the financing of education in a country proven to give positive and significant impact on the performance of national education. Thus, low budget for education in a country will give unfavorable influence on the quality of service of the educational process, which is reflected in less inequality in educational opportunities for children from poor family background, poor education, and less capable.

The impact of the lack of education budget to support the needs of education in Indonesia has implications for the cost of education, both at the elementary, secondary, and higher education. This is not the case in Indonesia alone. In the United States, the period 1990-2000 the cost of higher education has increased significantly. The Board College (1999) in Paulsen [1] estimated that in 1999-2000 the average cost required to enter higher education amounted to \$ 15.380 for private higher education and $\$ 3.356$ for state higher education, not including room rental and other expenses that could reach $\$ 7,000$. During the 1980 s, the cost of going to college increased two to three times the rate of inflation, and after accounting for the effects of inflation in the 1990s, the cost of going to college increased $51 \%$ for public universities and $34 \%$ for private universities, Taking into account the ability to pay, according to the report of the Committee on Higher Education also pointed to low-income families, the cost of going to college has increased from $91 \%$ in 1971-72 to $160 \%$ in $1999-2000$ to their incomes.

In China, debates about higher education finance led to the introduction of a cost-sharing model, whereby students were required to pay tuition fees, over a decade ago. However, there is still significant resistance towards such a system within the broader society [5]. In Nigeria, it has been revealed that there were overspending on general administration, general academic and retirement benefits at the expense of research and public service [6]. In Uganda, there is a need for private 
universities to know how to generate additional income to fund not only their operations, but also to ensure an annualised profit as a buffer against any inevitable fluctuations [7].

Based on the above, this study aims to determine how the process of preparation and execution of the budget in universities.

\section{LITERATURE REVIEW}

According to Thomas H. Jones in his "Introduction to school Finance, Technique and Social Policy" [2], discloses principles or education funding model imposed by the government, namely:

1) Flat Grant, this model distributed state funds without considering the amount of money collected by local tax or sharing equally.

2) Full State Funding, this model of financing is borne entirely by the state ie remove all local differences, both in spending and in tax revenue.

3) The Foundation Plan, this model is emphasized in the benchmark minimum property tax rate and minimum spending level for each local school district in the state.

4) Guaranteed Tax Base, this model is a matching plan, which the state pays a certain percentage of the total cost of education desired by each school district.

5) Percentage Equalizing, this model is a form of Guaranteed Tax Base, which the state guarantees to integrate the levels of spending in the first year of the local district with the reception of the resources of the state and the match is at a variable rate.

6) Power Equalizing, this model ordered districts very rich to pay some taxes in the school that they're picking the pockets of the state government. Models and provisions for school funding so diverse. To see which model best be evaluated by considering certain aspects of the formulation and the provisions in the financing of schools assessed based on the criteria for identifying the overall characteristics of a school funding program. Deddi Nordiawan [3], mentions the principles of financing relating to the role and function of education funding as a guideline, namely: Authorization by the legislature; Comprehensive ; Integrity means that all revenues and expenses are included in the general fund; nondiscretionary appropriation, the legislature approved amount should be utilized economically; Periodic; Accurate; Obviously; and Transparency.

While the budget preparation procedure is as follows: Identify the activities that will be conducted during the budget period; Identify sources expressed in money, services and goods; All resources stated in the form of money because the budget is basically a financial statement; Formulating the budget in a format that has been approved and used by certain institutions; Prepare a budget proposal to acquire of the authorities; Revise budget proposal; Approval of the revised proposed budget; and Approval of the budget.
Shape procedures and preparation of the budget is expected to be a reference organization in using the cost so it will not get off track of the direction and goals that were set. This process must be accurate and clear so that the preparation is not convoluted and make those plays can understand and carry out their duties with professional1. Yoyon [4] explains that the budget forms or financing, namely:

a) Articles of item-by-item (line item budget) is a form of conventional budget, but the most simple and widely used.

b) The budget program (program budget system) designed to identify each program. Program budget is calculated based on the type of program that has been planned.

c) Budget performance (performance-based budget) emphasize on performance (performance) and not on of detail of a budget allocation. Budget based on these results is a management tool that can clearly identify the unit of the result of a program and at the same grain detailing of activities that should be funded.

d) PPBS / SP4 (Planning Programming Budgeting System / System Planning Programming and Budgeting). This form popularized by Robert McNamara in 1960 in the United States. PPBS / SP4 is a framework in planning by organizing and analyzing information systematically.

e) Zero-Based Budgeting (Zero Based Budget / ZBB). Shape this budget define any activity or program that have been held in previous years should be evaluated to determine whether there should be or not to see the contribution to organizational goals.

Thus, basically the cost incurred in the field of education as a form of long-term investment that can yield benefits both of financial and non-financial. The cost of education is basically divided into two categories, namely direct costs and indirect costs to support the implementation of the educational process of the university.

\section{RESEARCH METHODOLOGY}

The method used in this study is the case study method with qualitative approach. In this dissertation research, the research method used was a case study (case study research), which is trying to learn a phenomenon in the case and in a real context. The aim is to analyze in depth the whole phenomenon that is the cycle of the focus of the investigation in order to establish a broader generalization. In using this qualitative approach, the researchers used the logic of inductive thinking that departs from the rules that are specific to the general. A short description of the actual implementation of this method departs and is identical to the schools of post-positivistic. It was based on the fact that qualitative methods in social research departs from the paradigm that every aspect of social reality viewed holistically as a natural unity which need to be interpreted in depth, especially social reality is understood as a pluralistic reality. On this basis then qualitative methods more emphasis on the search for meaning behind of social reality so that a deep understanding of social reality are all concerned in this method. The object of this study was conducted in 3 Universities, the Institut Teknologi Bandung (ITB), 
Universitas Pendidikan Indonesia (UPI), and Institut Pertanian Bogor (IPB). Three State Universities which have the same characteristics, which has a study program ranging from Diploma Program, S1, S2, and S3, as well as get funding from the government.

\section{FINDING}

Basically college cost analysis of higher education as part of the preparation work and the annual budget of the college, so it has a system for recording costs and performing all costs both from the government or sourced from other funds (nongovernmental) in accordance with regulations set. This became the basis for higher education policy development accountably and transparently in order to improve the quality of education in universities.

In the appendix Permendikbud Number 93 Year 2014 on Procedures for Determining Standards Unit Operating Costs Universities Legal Entities that, the standard-setting unit operating costs are calculated based on the needs of education operational costs in making education prepared in accordance with the Standards of Service / Contract Performance PTNBH. To calculate the Standard Unit Operational Cost is used the calculation method of activity-based costing with a financing model that is direct costs and indirect costs in education, then any kind of courses held, the level of expensiveness area where PTN-BH is located (geography), and compliance with national standards of higher education is the standard of service / contract performance-BH State to the Minister.

Based on the field findings related to the budget that basically every college formulate the overall needs of each unit to support the process of education by considering the various components in establishing policies that will be implemented.

Besides making needs to be formulated amount of the allocation will be set also contained the involvement of various units in formulating achievement targets will be based on the performance analysis of each work unit formulation.

Based on these findings, we can conclude that basically college education cost analysis as part of the preparation of the annual budget and work colleges. This became the basis for higher education policy development accountably and transparently in order to improve the quality of education in universities.

In the implementation and distribution of the budget, each unit in this case study programs are grouped based on the structure of the cost of organizing courses, ranging from courses which happen to be dominated by the learning activities in the classroom, practicum and laboratory with various need materials and equipment, including the needs of the fee, In the Appendix Permendikbud Number 93 Year 2014 on Procedures for Determining Standards SBOP there are twelve groups of two-dimensional views differentiator, as follows: Breakdown by type of course; and Grouping based on the learning process.

Higher education has a purpose for uphold the truth, then as an organizer of Higher Education should be free from the influence and contamination of any kind of political force or economic power, so Universities can conducted under the principles of academic freedom and autonomy of science. Therefore, the State duty to protect and ensure through the establishment of various laws and regulations, among others, is a Government Regulation on Forms and Higher Education Funding Mechanisms contained in the Law Firm PP No. 26 of 2015. In mentioned in Chapter IV of the Education Accountability high domestic legal entity in chapter 20, namely

1) The Chief State Legal preparing performance reports and financial statements PTN Law Firm year budget to be submitted to the panel of trustees, minister, and minister government affairs in the financial sector.

2) The report on the performance of State Legal Entity arranged in a systematic, accurate, and accountable.

3) The financial statements have been prepared based PTN Law Firm generally accepted accounting principles match with financial accounting standards established by the Indonesian Institute of Accountants.

4) The financial report referred to in paragraph (3) shall consist of: Statement of financial position (balance sheet); Activity reports; Cash flow statement; and Notes to financial statements.

5) Further provisions on the performance report referred to in paragraph. Basically each university must submit all reports of programs and activities that have been done as a form of which has been planned on until the monitoring and evaluation of both the budget of the Rector, the Directorate, faculty and study program. On the other hand in the budget execution process involving various stakeholders who have the authority and responsibility in the budget aspect.

\section{CONCLUSION}

Based on the results of empirical findings can be concluded that basically in-budgeting there are many components that need to be formulated based on the type and priority needs to be defined because it will affect the amount of the unit cost of education to be set. The budget process at all three universities are arranged top down, which means that the unit of work to get the determination of the budget ceiling first, then programs and activities prepared in accordance with the budget limit that has been set.

In the implementation and distribution of the budget are grouped based on the structure of fees to the needs of the smallest unit of work (in the program). It also refers to the attachment of Culture Ministerial Regulation on Procedures for Determining Standards SBOP. Moreover, basically every college expressed openly and transparently from planning to the implementation of the monitoring and evaluation of programs and activities that have been performed throughout the unit of work in college, because in managing the financing of education involving the various parties concerned. 


\section{References}

[1] Michael . Paulsen, John C. Smart, (2001). The finance of higher education : Theory, Research, Policy \& Practice, New York: Agathon Press.

[2] Jones, Thomas H., (1985). Introduction to school finance technique and social policy, New York : Macmillan Publishing Company

[3] Nordiawan, Deddi. (2006). Akuntansi sektor publik. Jakarta: Salemba Empat.

[4] Yoyon Bahtiar Irianto, (2008). Studi Evaluatif Tentang Efektivitas SistemPerencanaan Pendidikan Tingkat Kabupaten/Kota; Studi Kasus pada Proses Perencanaan Pembangunan Bidang Pendidikandi Kabupaten Bandung Menuju Tahun 2025.Disertasi. UPI. Bandung.

[5] Li Fengliang, (2012). Financing higher education: lessons from China. Irish Educational Studies, 31:2, 191-206

[6] Joel B. Babalola, (1998). Cost and financing of university education in Nigeria. Higher Education 36: 43-66, 1998

[7] Mark Olweny, (2011). Determining the Unit Cost of Higher Education: The Case of the Faculty of the Built Environment at Uganda Martyrs University, November, pp 241-247, 2011. 